\title{
Dermatophytes Isolated From Dogs and Cats Suspected Dermatophytoses in Istanbul, Turkey Within A 15-Year-Period: An Updated Report
}

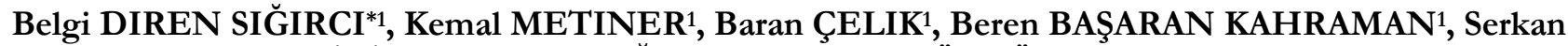 \\ İKİZ1, A. Funda BAĞCIGIL ${ }^{1}$, N. Yakut ÖZGÜR ${ }^{1}$, Seyyal AK ${ }^{1}$ \\ ${ }^{1}$ Department of Microbiology, Faculty of Veterinary Medicine, Istanbul University Cerrahpasa, TR 34320 Avclar, \\ Istanbul - TURKEY
}

\begin{abstract}
The present research was aimed to determine the prevalence of dermatophytes isolated from symptomatic dogs and cats, within a 15-year-period, in the city of Istanbul, Turkey. Dermatological specimens were collected from 1504 dogs and 846 cats, which were presented clinical signs of ringworm. Direct microscopy and mycological cultures were performed. The fungal growth rate was detected at $8.2 \%$ and $22.8 \%$ from dogs and cats, respectively. Microsporum canis was the most frequently isolated species followed by Trichophyton spp., M. gypseum, T. mentagrophytes, M. nanum, other Microsporum spp. moreover T. tonsurans. The cats less than two-year age and more than ten-year age showed a statistically significant higher isolation rate of infection $(p<0.05)$. There were no statistically significant differences between the age of the dogs and the dermatophyte isolation rate and between the gender of the dogs and cats and the dermatophyte isolation rate. As a conclusion, the data suggest an updated report on local epidemiology and define potential etiologic agents.
\end{abstract}

Keywords: Dermatophytoses, Dog, Cat, Mycological Culture, Microsporum spp., Trichophyton spp.

15-Y1llık Periyotta İstanbul Türkiye’de Dermatofitoz Şüpheli Köpek ve Kedilerden İzole Edilen Dermatofitler: Güncellenmiş Rapor

ÖZ

$\mathrm{Bu}$ araştırma, İstanbul ilinde 15 yıllık bir süre içinde semptomatik köpek ve kedilerden izole edilen dermatofitlerin yaygınlığını belirlemeyi amaçlamıştır. Dermatolojik örnekler ringworm klinik belirtileri gösteren 1504 köpek ve 846 kediden toplandı. Direkt mikroskopi ve mikolojik kültürler yapıldı. Mantar üreme oranları, köpeklerde \% 8.2 kedilerde \% 22.8 olarak saptandi. En sık izole edilen tür Microsporum canis idi. Bunu Trichophyton spp., M. gypseum, T. mentagrophytes, M. nanum, diğer Microsporum spp. ve T. tonsurans takip etti. İki yaşından küçük ve on yaşından büyük kediler, istatistiksel olarak anlamlı derecede yüksek bir etken izolasyon oranı gösterdi ( $\mathrm{p}<0.05)$. Köpeklerin yaşı ve dermatofit izolasyon oranlan ile kedi ve köpeklerin cinsiyeti ve dermatofit izolasyon oranları arasinda istatistiksel olarak anlamlı bir fark bulunmadı. Sonuç olarak, veriler yerel epidemiyoloji üzerine güncel bir rapor sunmakta ve olası etiyolojik ajanları tanımlamaktadır.

Anahtar Kelimeler: Dermatofitler, Köpek, Kedi, Mikolojik Kültür, Microsporum spp., Trichophyton spp.

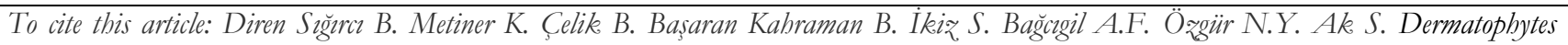
Isolated From Dogs and Cats Suspected Dermatophytoses in Istanbul, Turkey Within A 15-Year-Period: An Updated Report. Kocatepe Vet J. (2019) 12(2):116-121.

Submission: 12.12.2018 Accepted: 25.03.2019 Published Online: 29.03.2019

ORCID ID; BDS: 0000-0001-7153-7428, KM: 0000-0003-4105-5852, BÇ: 0000-0001-9122-0284,

BBK: 0000-0002-1736-093X, Sİ: 0000-0001-6502-0780, AFB: 0000-0002-8838-7291, NYÖ: 0000-0001-6052-1324,

SA: 0000-0002-6687-8401

*Corresponding author e-mail: belgis@istanbul.edu.tr 


\section{INTRODUCTION}

Dermatophytoses in companion animals, especially dogs and cats, is a common skin disease caused by keratinophilic dermatophytes. More than 30 species of dermatophytes have been identified; however, Microsporum canis, Microsporum gypseum and Trichophyton mentagrophytes are the primary etiological agents. Because of the pleomorphic presentation of symptoms, contagious nature, and zoonotic importance, dermatophytoses is recognised as one of the major public health problems worldwide (Moriello et al. 2017, Paterson 2017). It has been emphasised that approximately $20-50 \%$ of human skin infections were caused by zoonotic dermatophytes (Murmu et al. 2015, Weese and Fulford 2010).

Companion animals showed a higher prevalence and considered as the main source of human dermatophyte infections (Khosravi and Mahmoudi 2003, Mancianti et al. 2002, Seker and Dogan 2011). The spread of dermatophytes from animals to humans may usually occur by direct contact or indirectly through infected hair and scales from animals (Khosravi and Mahmoudi 2003). The spreading of dermatophyte infections is crucial to describe the infective routes to determine the possible sources of infection, or to identify the dissemination areas of the pathogens (Kanbe et al. 2003).

Various studies have been documented that the prevalence of dermatophytoses ranges worldwide ranges within $4 \%$ to $20 \%$ in dogs and more than $20 \%$ in cats (Brilhante et al. 2003, Mattei et al. 2014, Moriello et al. 2017, Nichita and Marcu 2010, Paterson 2017). Besides, in Turkey, İlhan et al. (2016), Seker and Dogan (2011) and Tel and Akan (2008) have determined the prevalence of these infections and the ranges were between $8 \%$ and $19 \%$ in dogs, while $7 \%$ and $72 \%$ in cats. Most studies have focused that $M$. canis is the ubiquitous dermatophyte isolated from suspected animals. Moreover, $M$. canis, as well as M. gypseum and T. mentagrophytes, are the fungus responsible for more than $95 \%$ of all dermatophytoses cases in companion animals (Mattei et al. 2014). The understanding of ringworm presence is essential for decreasing the transmission of fungal infections to animals and humans. The present study aimed to determine the prevalence of the predominant pathogenic dermatophyte species from symptomatic dogs and cats, within a 15-year-period, to present an updated report on local epidemiology and identify possible pathogens, in the city of Istanbul, Turkey.

\section{MATERIALS and METHODS}

\section{Collection of samples}

Cases clinically suspected of dermatophytoses and presented at the Department of Internal Medicine were included in the study. At the fifteen-year period, between 2003 and 2017, the samples were obtained from 1504 dogs and 846 cats. Diagnosis of the disease was based on historical data, clinical signs or findings on physical examination. Alopecia and desquamation were reported by veterinary practitioners and consecutively classified as suspected cases of dermatophytoses. Plucked hairs and scraped scales of each animal were collected from the lesions using a sterile lancet by veterinary practitioners and placed in sterile petri dishes. All samples were processed within 2 hours.

Demographic data on patients' sex and age were gathered from each medical record. Three age group were selected for this study; less than two years, 2-10 year, and more than ten years. We did not have age data of 420 dogs and 362 cats, and sex data of 320 dogs and 139 cats did not extract.

\section{Direct microscopic examination}

The 'gold standard' diagnostic techniques were applied for identification of dermatophytoses such as direct microscopic examination of clinical specimens (Debnath et al. 2016, Mattei et al. 2014). All samples were examined for fungal elements in $10 \%$ potassium hydroxide $(\mathrm{KOH})$ under a light microscope at $40 \times$ magnification.

\section{Mycologic culture}

The samples were inoculated onto Sabouraud Dextrose Agar (SDA) (HiMedia Laboratories, Mumbai, India, Catalogue No. M063) supplemented with cycloheximide and chloramphenicol, and Dermatophyte Test Medium (DTM) (HiMedia Laboratories, Mumbai, India, Catalogue No. M188). The plates were incubated at $25^{\circ} \mathrm{C}$ for up to 3 weeks and were observed periodically for the appearance of fungal growth. The identification of the cultures was made according to "dermatophytes identification scheme". The macroscopical examination of cultures was established by the colony morphology, pigmentation and growth rate. The microscopic examination was formed by lactophenol cotton blue staining by their size, shape, presence of septa, the thickness of conidial wall and arrangement of conidial cells around the hyphae (de Hoog et al. 2000, Koneman and Roberts 1985).

\section{Statistical analyses}

Chi-square $\left(x^{2}\right)$ test was used to examine the statistical significance of gender and age in the distribution of positive cultures in dogs and cats separately. The cats and dogs, which have age and gender data, were involved in statistical analyses. $p$ value of $<0.05$ was considered significant. SPSS 13.0 software was used for statistical analysis. (Özdamar 2003).

\section{RESULTS}


Dermatological specimens were collected from 1504 dogs and 846 cats. In dogs, 626 were female while 558 of were male and in cats, 389 were female while 318 of were male. Three hundred twenty-five of the dogs were $<2$ year, 553 of were between 2 and 10 years while 206 of were $>10$ years. Two hundred nine of the cats were $<2$ years, 221 of were between 2 and 10 years while 54 of were $>10$ year.

At the results of the direct microscopic examination of hair samples belonging to 1504 dogs and 846 cats, fungal elements were observed in 56,5\% and 58,2\% of clinical specimens, respectively. $60 \%$ of the dog samples and $69,9 \%$ of the cat samples containing fungal elements were also positive for culture.

According to the fungal culture, the colony that were white or yellowish colour; plane, velvety or cottony surface and brown or golden-yellow reverse in SDA were identified as Microsporum spp. The appearance of white aerial hyphae and red colour around the colony in DTM demonstrated the presence of Microsporum spp. The colony that was powdery to a granular surface; plane, white to cream colour and reverse yellowish brown to reddish-brown in SDA were identified as Trichophyton spp. White colonies and a red colour change develop in the medium around the fungal growth in DTM were positive for the presence of Trichophyton spp.. Macroscopic appearance of M.canis and T. mentagrophytes isolates on SDA, and microscopic appearance under a light microscope at a $40 \times$ magnification of isolates stained by lactophenol cotton blue are shown in Figure 1.
Overall, dermatophytoses were detected in 317 of $2350(13.5 \%)$ samples. The fungal growth rates were $8.2 \%$ and $22.8 \%$ from dogs and cats, respectively. $M$. canis was the most frequently isolated species from dogs and cats (64.4\%), followed by Trichophyton spp., M. gypseum, T. mentagrophytes, Microsporum nanum, other Microsporum spp., and Trichophyton tonsurans. The distribution of dermatophytes isolated from dog and cat skin scrapings according to the species are shown in Table 1.

Dermatophyte identification was observed mostly in the dogs between 2 and 10 years (n: 53) and in the cats, the maximum identification was detected from the under two years animals (n: 87). Four hundred twenty dogs and 362 cats did not have age data; therefore, these animals were not included in the statistical analysis. The cats less than two-year age and more than ten-year age showed a statistical significance $(p<0.05)$. There were no statistically significant differences between the age of the dogs and the dermatophyte isolation rate. The age and isolation rates of dogs and cats with dermatophytoses are shown in Table 2 and Table 3, respectively.

Dermatophyte identification was observed similarly in male and female dogs and cats. Three hundred twenty dogs and 139 cats did not have sex data; therefore, these animals were not included in the statistical analysis. There were no statistically significant differences between the gender of both dogs and cats, and the dermatophyte isolation rate. The gender and isolation rates of dogs and cats with dermatophytoses are shown in Table 4 and Table 5 , respectively.
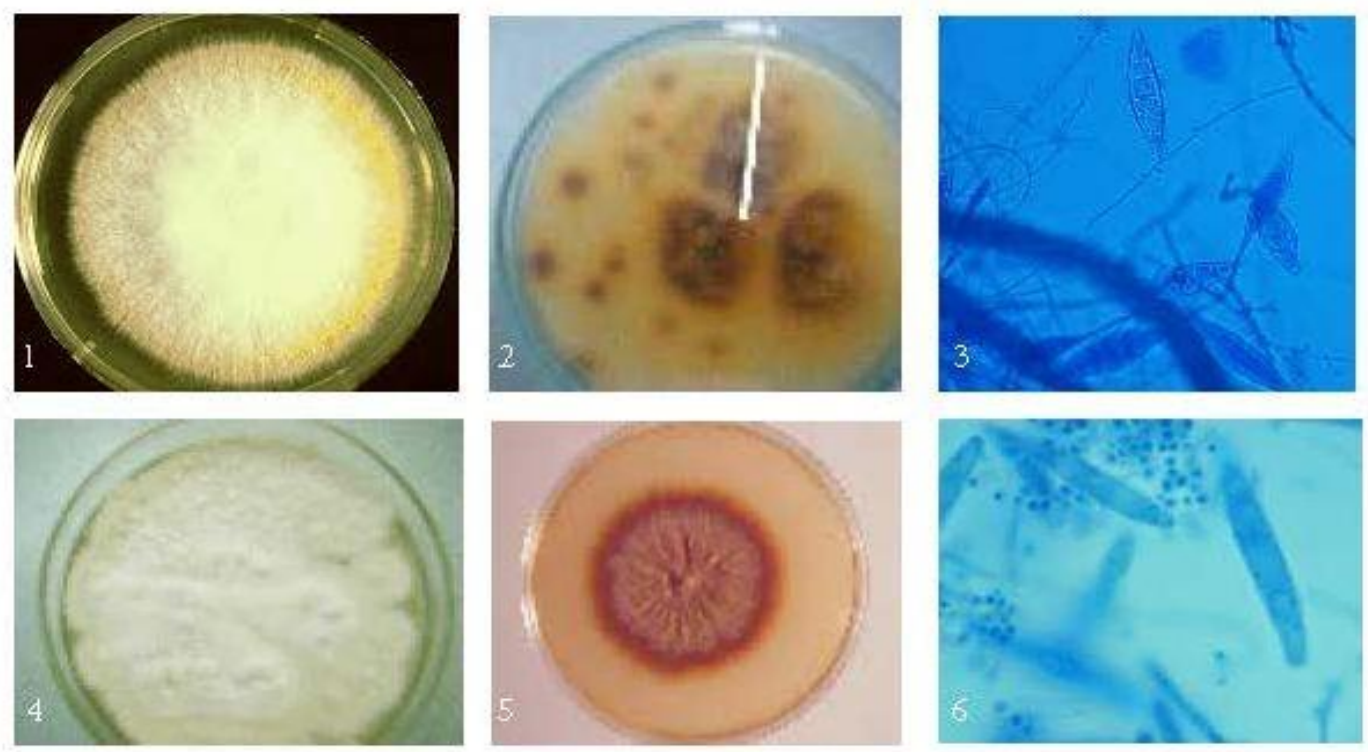

Figure 1. The macroscopic and microscopic appearance of M.canis and T. mentagrophytes isolates

1.M.canis on SDA 2. M.canis on SDA, reverse 3. Microscopic appearance of M.canis at a

$40 \times 4$. T. mentagrophytes on SDA 5. T. mentagrophytes on SDA, reverse 6. Microscopic

appearance of T. mentagrophytes at a $40 \times$

Table 1. The distribution of dermatophytes isolated from dog and cat skin scrapings according to the species 


\begin{tabular}{cccc}
\hline Dermatophytes & Dogs & Cats & Total \\
\hline M. canis & $63(50.8 \%)$ & $141(73 \%)$ & $204(64.4 \%)$ \\
M. gypseum & $9(7.3 \%)$ & $28(14.5 \%)$ & $37(11.7 \%)$ \\
M. nanum & $7(5.6 \%)$ & $3(1.6 \%)$ & $10(3.1 \%)$ \\
Other Microsporum spp. & $3(2.4 \%)$ & $4(2.1 \%)$ & $7(2.2 \%)$ \\
T. mentagrophytes & $12(9.7 \%)$ & $5(2.6 \%)$ & $17(5.4 \%)$ \\
T. tonsurans & $1(0.8 \%)$ & $0(-)$ & $1(0.3 \%)$ \\
Trichophyton sp. & $29(23.4 \%)$ & $12(6.2 \%)$ & $41(12.9)$ \\
\hline Total & 124 & 193 & 317 \\
\hline
\end{tabular}

Table 2. The age and isolation rates of dogs with dermatophytoses

\begin{tabular}{cccc}
\hline Dogs & Dermatophytoses positive & Dermatophytoses negative & Total \\
\hline$<$ 2 year & $38(11.6 \%)$ & $287(88.4 \%)$ & $325(100 \%)$ \\
2-10 year & $53(9.5 \%)$ & $500(90.5 \%)$ & $553(100 \%)$ \\
$>$ 10 year & $16(7.7 \%)$ & $190(92.3 \%)$ & $206(100 \%)$ \\
\hline Total & 107 & 977 & 1084 \\
\hline
\end{tabular}

Table 3. The age and isolation rates of cats with dermatophytoses

\begin{tabular}{cccc}
\hline Cats & Dermatophytoses positive & Dermatophytoses negative & Total \\
\hline <2 year & $87(41.6 \%)^{*}$ & $122(58.4 \%)$ & $209(100 \%)$ \\
2-10 year & $43(19.4 \%)$ & $178(80.6 \%)$ & $221(100 \%)$ \\
$>$ 10 year & $29(53.7 \%)^{*}$ & $25(46.3 \%)$ & $54(100 \%)$ \\
\hline Total & 159 & 325 & 484 \\
\hline
\end{tabular}

* There is a statistical difference $(\mathrm{p}<0.05)$ between groups.

Table 4. The gender and isolation rates of dogs with dermatophytoses

\begin{tabular}{cccc}
\hline Dogs & Dermatophytoses positive & Dermatophytoses negative & Total \\
\hline Male & $50(8.9 \%)$ & $508(91.1 \%)$ & $558(100 \%)$ \\
Female & $55(8.7 \%)$ & $571(91.3 \%)$ & $626(100 \%)$ \\
\hline Total & 105 & 1079 & 1184 \\
\hline
\end{tabular}

Table 5. The gender and isolation rates of cats with dermatophytoses

\begin{tabular}{cccc}
\hline Cats & Dermatophytoses positive & Dermatophytoses negative & Total \\
\hline Male & $66(20.7 \%)$ & $252(79.3 \%)$ & $318(100 \%)$ \\
Female & $93(23.9 \%)$ & $296(76.1 \%)$ & $389(100 \%)$ \\
\hline Total & 159 & 548 & 707 \\
\hline
\end{tabular}

\section{DISCUSSION}

Dermatophytoses are common worldwide and continue to increase, and thus several reports are available on the prevalence of the infection as varying. Murmu et al. (2016) indicated that the incidence of dermatophytoses in cats was the highest $(55.5 \%)$ than dogs. Nweze (2011) and Esch and Peterson (2013) who observed a 58-67\% occurrence rate in their studies was supported this high prevalence. The prevalence of dermatophytoses in dogs were reported by Brilhante et al. (2003) (14.3\%),
Nichita and Marcu (2010) (16.8\%) and Mancianti et al. (2002) (18.7\%). However, Khosravi and

Mahmoudi (2003) indicated that $8.2 \%$ of samples from dogs were found positive about dermatophytoses. Seker and Dogan (2011) were determined $20.1 \%$ as positive for dermatophytes.

In the present study, the dermatophyte isolation rates from dogs and cats were $8.2 \%$ and $22.8 \%$, respectively. Our findings showed roughly similarity with these results. Contrary to this, the studies that had higher results were reported by Faggi et al. (1987), Seker and Dogan (2011) and Moriello et al. 
(2017). These differences are not surprising, and it may be originated because of the full range in methodologies. Moreover, the author reported that the prevalence of dermatophytes depends on geographical location, the season of sampling, clinical, and living conditions (Proverbio et al. 2014).

M.canis is a pathogenic fungal species that causes a superficial skin infection called dermatophytoses in domestic carnivores while they can be transmitted to human beings with close contact of the affected animal (Moriello et al. 2017). The cats are reported as the principal reservoir for this pathogen. Nichita and Marcu (2010) observed that the prevalence in cats is usually higher than in dogs. Mancianti et al. (2002), Brilhante et al. (2003) and Cafarchia et al. (2004) reported similar results. According to the results from this study, $M$. canis was the most common causative agent of dermatophyte isolated, and it is in agreement with the reports obtained (Brilhante et al. 2003, Mancianti et al. 2002).

Dermatophytoses studies have been described throughout the world; $M$. canis, $T$ mentagrophytes and M. gypseum were jointly responsible for almost all of the infections in dogs and cats. In the present study, the identified dermatophytes were $M$. canis $(\mathrm{n}=204)$, $M$. gypseum $(\mathrm{n}=37), M$. nanum $(\mathrm{n}=10)$, other Microsporum sp. $(\mathrm{n}=7), T$. mentagrophytes $(\mathrm{n}=17), T$. tonsurans $(\mathrm{n}=1)$ and other Trichophyton sp. $(\mathrm{n}=41)$. These data almost correspond to the situation in Turkey where these species are the most common fungus, which has been seen in dogs and cats. Tel and Akan (2008) determined the distribution of isolated strains as $95.9 \% M$. canis and $4.1 \% M$. nanum in cats; $50 \%$ M. canis, $18.7 \%$ T. mentagrophytes, in dogs in Ankara. Seker and Dogan (2011) indicated that $M$. canis was the most common dermatophyte isolated from dogs $(46 \%)$ and cats $(69.7 \%)$, followed by $T$. mentagrophytes (32.4\%) in dogs in Ankara and Izmir. Ilhan et al. (2016) showed that the most frequently isolated fungi were $T$. terrestre $(4.1 \%)$, followed by $M$. gypseum $(1.1 \%), M$. nanum $(1.1 \%)$, and T. mentagrophytes $(0.7 \%)$ in cats in Van.

Moriello et al. (2017) identified the predispositions of the development of dermatophytoses in cats and dogs and underlined the being puppies and kittens, lifestyle, free-roaming animals and warm locations for the risk populations. Age was recognised as a predisposing factor by many researchers. Tel and Akan (2008) found the prevalence to be significant $(\mathrm{p} \leq 0.01)$ in animals that were smaller than one year old. Mattei et al. (2014) determined that the animals younger than one-year-old appear to be susceptible to dermatophytoses. Contrary to these findings, Seker and Doğan (2011) detected no significant difference statistically between the age groups and the prevalence rate. In this study, there was a significant difference in the distribution of positive cultures in cats less than two-year age and more than ten-year age. According to our findings, the higher susceptibility of young and old cats may be related to the immunological condition and deficiency of fungistatic linoleic acid.

Several researchers did not detect any correlation between sex and the presence of infections (Mancianti et al. 2002, Mattei et al. 2014, Seker and Dogan 2011). Therewithal, Pinter et al. (1999) and Cafarchia et al. (2004) have reported that male dogs were most often affected by dermatophyte infections. Also, Iorio et al. (2007) were detected the prevalence rate of dermatophytes in female cats more than male cats and Cafarchia et al. (2004) were reported the prevalence rate of $M$. canis in female cats more than male cats. In the current study, the isolation rate of dermatophytes in female and male animals was not found to be significant.

\section{CONCLUSION}

The present study emphasised that fungal infections are ubiquitous in companion animals such as cats and dogs and $M$. canis is usually the first animal-associated fungus causing infections. As a conclusion, the data suggest an updated review of local epidemiology and clarify possible etiologic agents, and this study will provide valuable information on current epidemiological trends for fungal infections in Turkey.

\section{REFERENCES}

Brilhante RSN, Cavalcante CSP, Soares-Junior FA, Cordeiro RA, Sidrim JJC, Rocha MFG. High rate of Microsporum canis feline and canine dermatophytoses in Northeast Brazil: epidemiological and diagnostic features. Mycopathologia. 2003; 156: 303-308.

Cafarchia C, Romito D, Sasanelli M, Lia R, Capelli G, Otranto D. The epidemiology of canine and feline dermatophytoses in southern Italy. Mycoses. 2004; 47: 508-513.

de Hoog GS, Guarro J, Gené J, Figueras MJ. Atlas of Clinical Fungi, Second Edition, Washington, DC, USA. American Society for Microbiology, 2000.

Debnath C, Mitra T, Kumar A, Samanta I. Detection of dermatophytes in healthy companion dogs and cats in eastern India. Iranian journal of veterinary research. 2016; 17(1): 20

Esch KJ, Peterson CA. Transmission and epidemiology of zoonotic protozoal diseases of companion animals. Clin. Microbiol. Rev. 2013; 26(1): 58-85.

Faggi E, Saponetto N, Sagone M. Dermatophytes isoles dês carnivores domestiques à Florence (Italie); enquête épidémiologique. Bull Soc Fr Mycol Méd. 1987; 1: $297-$ 302.

Ilhan Z, Karaca M, Ekin IH, Solmaz H, Akkan HA, Tutuncu M. Detection of seasonal asymptomatic dermatophytes in Van cats. Braz J Microbiol. 2016; 47(1): 225-230. 
Iorio R, Cafarchia C, Capelli G, Fasciocco D, Otranto D, Giangaspero A. Dermatophytoses in cats and humans in central Italy: epidemiological aspects. Mycoses. 2007; 50: 491-495.

Kanbe T, Suzuki Y, Kamiya A, Mochizuki T, Fujihiro M, Kikuchi A. PCR-based identification of common dermatophyte species using primer sets specific for the DNA topoisomerase II genes. J Dermatol Sci. 2003; 32: 151-161.

Khosravi AR, Mahmoudi M. Dermatophytes isolated from domestic animals in Iran. Mycoses. 2003; 46: 222-225.

Koneman EW, Roberts GD. Practical Laboratory Mycology. 3rd ed. Baltimore: Williams \& Wilkins; 1985. Dermatophyte identification schema.

Mancianti F, Nardoni S, Cecchi S, Corazza M, Taccini F. Dermatophytes isolated from symptomatic dogs and cats in Tuscany, Italy during a 15-year-period. Mycopathologia. 2002; 156: 13-18.

Mattei AS, Beber MA, Madrid IM. Dermatophytosis in Small Animals. SOJ Microbiol Infect Dis. 2014; 2(3): 1-6.

Moriello KA, Coyner K, Paterson S, Mignon B. Diagnosis and treatment of dermatophytosis in dogs and cats. Clinical Consensus Guidelines of the World Association for Veterinary Dermatology. Vet Dermatol. 2017; 28(3): 266268.

Murmu S, Debnath C, Pramanik AK, Mitra T, Jana S, Dey S, Batabyal, K. Detection and characterization of zoonotic dermatophytes from dogs and cats in and around Kolkata. Vet World. 2015; 8(9): 1078.

Nichita I, Marcu A. The Fungal Microbiota Isolated from Cats and Dogs. J Anim Sci Technol. 2010; 43: 411-414.

Nweze EI. Dermatophytoses in domesticated animals. Rev. Inst. Med. Tro. 2011; 53(2): 95-99.

Özdamar K. SPSS ile Biyoistatistik. Kaan kitabevi, Türkiye. 2003.

Paterson S. Dermatophytosis: an update. Companion Anim. 2017; 22(5): 248-253.

Pinter L, Jurak Z, Ukalovic M, Susic V. Epidemiological and clinical features of dermatophytoses in dogs and cats in Croatia between 1990 and 1998. Vet Arhiv. 1999; 69: 261-270.

Proverbio D, Perego R, Spada E, Bagnagatti de Giorgi G, Della Pepa A, Ferro E. Survey of dermatophytes in stray cats with and without skin lesions in Northern Italy. Veterinary medicine international, 2014; 1-4.

Seker E, Dogan N. Isolation of dermatophytes from dogs and cats with suspected dermatophytosis in Western Turkey. Prev Vet Med. 2011; 98: 46-51.

Tel OY, Akan M. Kedi ve köpeklerden dermatofitlerin izolasyonu. Ankara Univ Vet Fak Derg. 2008; 55: 167 171.

Weese JS, Fulford M. editors. Companion Animal Zoonoses. New Jersey: Wiley-Blackwell; 2010. 278-279. 